\title{
Analysis of Severe and Critical COVID-19 Patients Treated With Favipiravir: A Retrospective Cohort Study
}

\section{Favipiravir ile Tedavi Edilen Ağır ve Kritik COVID-19 Hastalarının Analizi: Bir Retrospektif Kohort Çalışma}

\author{
• Bengü Şaylan, ๑ Tayfun Çalışkan \\ Health Sciences University Turkey, Sultan 2. Abdulhamid Han Training and Research Hospital, Clinic of Pulmonology, Istanbul, Turkey
}

Background: We aimed to analyze demographic characteristics, smoking status, comorbidities, laboratory parameters and other treatments before favipiravir use in severe to critically ill patients with coronavirus disease-2019 (COVID-19) who were treated with favipiravir in Turkey.

Materials and Methods: This study was conducted as a retrospective observational study in a tertiary reference hospital for COVID-19. Clinical and laboratory data of COVID-19 patients who were consecutively treated with favipiravir were evaluated. The patients were divided into two groups as survivors and non-survivors.

Results: The mean ages of the non-survivors and survivors were $67.3 \pm 13.3$ and $57.3 \pm 16.4$ years $(p<0.0001$ ), respectively. The smoking rate was $44.4 \%$ in non-survivor group and $9.1 \%$ in the survivor group $(p=0.01)$. Older age [odds ratio (OR): $1.04,95 \%$ confidence interval (Cl): 1.016-1.069], smoking (OR: 5.76, 95\% Cl: 1.84-18.03), presence of one or more comorbidity (OR: 4.43, 95\% $\mathrm{Cl}: 1.79-10.91)$, coronary artery disease (CAD) (OR: 2.66, 95\% Cl: 1.06-6.72), arrhythmia (OR: 3.4, 95\% Cl: 1.78-9.82) and congestive heart failure (CHF) (OR: 14.4, 95\% Cl: 2.9-71.43) were significantly related to mortality $(\mathrm{p}<0.05)$. The rate of patients who were treated with lopinavir/ritonavir before favipiravir was higher in the non-survivor group $(p=0.0001)$. Favipiravir treatment was started earlier in survivors than in non-survivors (3.1 \pm 2.2 and $4.7 \pm 3.4$ days, respectively, $\mathrm{p}=0.006$ ).

Conclusion: Older age, smoking, presence of one or more comorbidity, CAD, arrhythmia, CHF and treatment with lopinavir/ritonavir before favipiravir were associated with mortality. Favipiravir was started earlier in survivors. Oxygen saturation levels and platelet count increased, and C-reactive protein (CRP) and lactate dehydrogenase levels decreased with favipiravir treatment in survivors. Higher CRP levels were also associated with mortality.

Keywords: Favipiravir, mortality, COVID-19, comorbidity, coronavirus

Amaç: Türkiye'de favipiravir ile tedavi edilen ağır ve kritik koronavirüs hastalığı-2019 (COViD-19) hastalığı olan hastaların demografik özelliklerini, sigara içme durumunu, komorbiditelerini, laboratuvar parametrelerini ve favipiravir öncesinde uygulanan tedavileri analiz etmeyi amaçladık.

Gereç ve Yöntemler: Bu çalışma, COVID-19 için üçüncü basamak bir referans hastanesinde retrospektif bir gözlemsel çalışma olarak gerçekleștirildi. Favipiravir ile art arda tedavi edilen COVID-19 hastalarının klinik ve laboratuvar verileri değerlendirildi. Hastalar hayatta kalanlar ve kalmayanlar olarak iki gruba ayrıldı.

Bulgular: Hayatta kalmayanların ve hayatta kalanların yaş ortalaması sırasıyla $67,3 \pm 13,3$ ve $57,3 \pm 16,4$ ( $p<0,0001$ ) idi. Hayatta kalmayan grupta sigara içme oranı \%44,4, sağ kalan grupta ise \%9,1 idi ( $p=0,01)$. İleri yaş [olasılık oranı (00): 1,04,\%95 güven aralığı (GA): 1,016-1,069], sigara içme (00: 5,76, \%95 GA: 1,84-18,03), bir veya daha fazla komorbiditenin varlığı (00: 4,43, \%95 GA: 1,79-10,91), koroner arter hastalığı (KAH) (00: 2,66,\% 95 GA: 1,06-6,72), aritmi (00: 3,4,\% 95 GA: 1,78-9,82) ve konjestif kalp yetmezliği (KKY) (00: 14,4,\% 95 GA: 2,9-71,43) anlamlı şekilde mortalite ile ilişkiliydi (p<0,05). Favipiravirden önce lopinavir/ ritonavir ile tedavi edilen hastaların oranı hayatta kalmayanlar grubunda daha yüksekti ( $p=0,0001)$. Favipiravir tedavisi hayatta

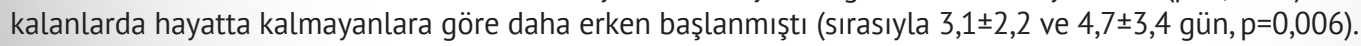

Address for Correspondence: Bengü Şaylan, Health Sciences University Turkey, Sultan 2. Abdulhamid Han Training and Research Hospital, Clinic of Pulmonology, İstanbul, Turkey Phone: +90 5054950181 E-mail: metebengu@yahoo.com ORCID ID: orcid.org/0000-0002-5922-0847

Received: 08.03.2021 Accepted: 22.03.2021 
Sonuç: İleri yaş, sigara kullanımı, bir veya daha fazla komorbiditenin varlığı, KAH, aritmi, KKY ve favipiravirden önce lopinavir/ ritonavir ile tedavi mortalite ile ilişkiliydi. Favipiravir hayatta kalanlarda daha erken başlandı. Hayatta kalanlarda favipiravir tedavisi ile oksijen satürasyonu seviyeleri ve trombosit sayısı arttı ve C-reaktif protein (CRP) ile laktat dehidrojenaz seviyeleri azaldı. Daha yüksek CRP seviyeleri de mortalite ile ilişkiliydi.

Anahtar Kelimeler: Favipiravir, mortalite, COVID-19, komorbidite, koronavirüs

\section{Introduction}

Currently, there is no approved drug except remdesivir for the treatment of the coronavirus disease-2019 (COVID-19); therefore, drugs approved for other diseases such as chloroquine, hydroxychloroquine, lopinavir/ritonavir and favipiravir are used experimentally in the treatment of COVID-19. There are differences among countries in terms of treatment protocols and the availability of the drug is one of the most important factors in this regard. Favipiravir is a purine analog which inhibits RNA-dependent RNA polymerase and was approved in Japan in 2014 to treat pandemic influenza virus infections (1). Favipiravir has been used for COVID-19 treatment considering that it may be effective in Severe acute respiratory syndrome coronavirus-2 (SARS-CoV-2), which is an RNA virus (2). Favipiravir has a broad-spectrum antiviral activity against different RNA viruses and a high barrier for resistance (3). Favipiravir is one of the potential candidates for the treatment of COVID-19 (4) and it may be a relatively safe and effective drug for COVID-19 (5). Favipiravir is frequently used for COVID-19 treatment in Turkey. This study was conducted to analyze demographic characteristics, smoking status, comorbidities, laboratory parameters and additional treatments in severe to critically ill patients with COVID-19 who were treated with favipiravir in Turkey.

\section{Material and Methods}

This is a retrospective observational study on adult inpatients ( $\geqslant 18$ years old) diagnosed with COVID-19 pneumonia and hospitalized in Umraniye Training and Research Hospital, which is a tertiary training hospital and also a COVID-19 reference center during pandemic, in Istanbul between March 25 and April 25, 2020. The study was approved by the Ethics Commission of Umraniye Training and Research Hospital (125/April 28, 2020) the requirement of informed consent was waived by the ethics commission. The COVID-19 guidelines of the Scientific Committee of Turkish Ministry of Health recommended favipiravir or lopinavir/ ritonavir for the treatment of patients with severe COVID-19 or patients who did not respond to initial treatment (6). Favipiravir was used only for the patients who had severe pneumonia with hypoxia described as oxygen saturation in room air $\left(\mathrm{SpO}_{2}\right)$ level $<90 \%$ in the room air. Lopinavir/ritonavir (400/100 mg, twice a day for 10-14 days) was recommended for patients who had severe COVID-19 pneumonia that did not respond to initial treatment but did not have the hypoxia criteria described above.

The eligibility criteria for the study were: 1 . Adults patients ( $\geqslant 18$ years old) diagnosed as COVID-19 with polymerase chain reaction (PCR) positivity, 2. Those diagnosed as COVID-19 based on clinical, laboratory and radiological findings especially with computed tomography (CT) findings despite COVID-19 PCR negativity, 3. Those who used favipiravir treatment for at least 5 days, based on the treatment protocol as favipiravir $1600 \mathrm{mg}$ twice a day for first day, then $600 \mathrm{mg}$ twice a day for four days, and 4. Patients who had $\mathrm{SpO}_{2}$ level $<90 \%$ in the room air and had COVID-19 pneumonia findings on chest CT. Exclusion criteria for the study: 1 . Those younger than 18 years old, 2. Patients with mild-to moderate disease, 3. Alanine transaminase (ALT), aspartate transaminase (AST) above 4 times higher or known chronic liver disease before treatment, 4. Human immunodeficiency viruses positive 5. $\mathrm{SpO}_{2} \geqslant 90 \%$ in room air, 6 . Patients those are not eligible for favipiravir, 7. Pregnant woman. SARS-CoV-2 detection in throat-swab specimens was conducted with next-generation sequencing or real-time RT-PCR methods.

Epidemiological, demographic, clinical, laboratory, treatment, and outcome data were extracted from electronic medical records of the hospital.Demographic information (age, gender), smoking history, symptoms, comorbidities including coronary artery disease (CAD), arrhythmia, hypertension, congestive heart failure (CHF), diabetes, chronic obstructive pulmonary disease (COPD), and asthma, malignancy history, immunosuppression and laboratory parameters including white blood cell, neutrophil, lymphocyte, platelet, ALT, AST, total bilirubin, direct bilirubin, lactate dehydrogenase (LDH), D-dimer, C-reactive protein (CRP), fibrinogen, and ferritin values were obtained. Smoking status was classified as actively smoking and not smoking. Treatment location, treatment with lopinavir/ritonavir before favipiravir, time to favipiravir treatment initiation and duration of favipiravir treatment after hospitalization were also noted. We grouped patients based on their radiology scores as mild for a total score between 1 and 5, moderate for a total score of 6-10, severe for a total score of $11-15$, and very severe for a total 
$>15$ by modifying the radiological scoring system offered for radiological severity assessment for COVID-19 (7). The patients were divided into two groups as those who died and survived. Clinical characteristics and laboratory parameters were compared between the two groups and before and after favipiravir treatment.

\section{Statistical Analysis}

While analyzing the data and performing the statistics of continuous structured data, the mean and standard deviation, the minimum and maximum values of the features were used. Frequency and percentage values were used to define categorical variables. Student's t-test statistics were used to compare the means of the two groups and paired t-test statistics were used to compare the means of the two dependent groups. The chi-square $\left(\chi^{2}\right)$ test statistics were used to evaluate the relationship between categorical variables. The exposure ratios [odds ratio (OR)] of variables thought to be related to death were given. To reveal the risk factors associated with in-hospital death, univariable logistic regression models were used. The statistical significance level of the data was accepted as $p<0.05$. In the evaluation of the data, www.e-picos.com New York software and MedCalc statistics package program were used to analyze the data.

\section{Results}

A total of 148 hospitalized, severe to critically-ill COVID-19 patients treated with favipiravir were enrolled in the study. Of the 148 patients, 53 (35.8\%) were females and $95(64.2 \%)$ were males and the mean age of the patients was $59.9 \pm 16.2$ years (Table 1$)$. Among them, 55 (37.2\%) patients were admitted to intensive care unit (ICU), 41 (27.7\%) of them were admitted to ICUs from the clinic and 14 (9.5\%) of them directly from the emergency department. 93 of the patients were treated for COVID-19 in clinic (Table 1). The patients were divided into two groups as non-survivors $(n=38)$ and survivors $(n=110)$. The mean age of the non-survivor group was $67.3 \pm 13.3$ years and the mean age of the survivors was $57.3 \pm 16.4$ years $(p<0.0001)$. Smoking rate was higher in the non-survivor group (44.4\%) than in the survivor group (9.1\%) $(p=0.01)$. Compared to patients who survived, non-survivors were older and there was no gender difference in two groups. The most common symptoms were fever (86.5\%), cough (65.5\%), dyspnea (35.8\%), gastrointestinal symptoms (22.3\%) and myalgia (19.6\%), respectively (Table 1 ). There was no statistically significant difference in terms of symptoms between the non-survivors and the survivors ( $p>0.05$ ).

Those with comorbid diseases were $81.6 \%$ of the nonsurvivor group and $50 \%$ of the survivors $(p=0.001)$ (Table 1$)$. Patients who died had higher rates of comorbidities including CAD ( $26.3 \%$ to $11.8 \%, p=0.03$ ), arrhythmia $(21.1 \%$ to $7.3 \%$, $p=0.03$ ), diabetes mellitus ( $21.1 \%$ to $7.3 \%)$ and Congestive heart failure (CHF) (36.8\% to $20.9 \%, p=0.0001$ ). Hypertension ( $50 \%$ to $37.3 \%$ ) was the most common comorbidity in two groups, but the difference between groups was not statistically significant $(p=0.17)$. There was no statistically significant difference between the non-survivors and survivors in terms of diabetes, COPD, asthma, immunosuppression, and malignancy history $(p>0.05)$.

The rate of patients who were treated with lopinavir/ ritonavir before favipiravir was higher in the non-survivor group than in the survivor group ( $47.4 \%$ vs. $10 \%, p=0.0001$ ). The relationship between the radiological stage of the disease and mortality was statistically significant $(p=0.002)$. Favipiravir treatment was started $4.7 \pm 3.4$ days after the hospitalization of the non-survivors and $3.1 \pm 2.2$ days after the hospitalization of the survivors $(p=0.006)$.

In the non-survivor group, neutrophil count $(7.6 \pm 4.4$ vs. $12.89 \pm 9.2, \quad p<0.0001)$, ferritin $(1274.1 \pm 1765.9$ vs. $5326.46 \pm 10309.4, p=0.02)$, fibrinogen $(647.8 \pm 160.4$ vs. $576.37 \pm 222.28, p=0.03)$, AST $(38.3 \pm 22.6$ vs. $99.21 \pm 123.71$, $p=0.004)$ and direct bilirubin $(0.3 \pm 0.2$ vs. $0.93 \pm 1.43$, $\mathrm{p}=0.01$ ) values were significantly different before and after favipiravir treatment (Table 2). Platelet count (209.2 \pm 80.9 vs. $333.7 \pm 143.1, p<0.0001)$, CRP $(69.5 \pm 63.9$ vs. $28.6 \pm 46.3$, $p<0.0001), L D H(633.8 \pm 824.7$ vs. $439.4 \pm 160.6, p=0.01), A L T$ ( $43.0 \pm 73$ vs. $72.4 \pm 76, p<0.0001)$ and total bilirubin $(1.2 \pm 5.0$ vs. $5.1 \pm 20.5, p=0.049)$ values were significantly different before and after favipiravir treatment in survivors. AST, direct bilirubin, neutrophil, and ferritin values increased, and $\mathrm{SpO}_{2}$ and fibrinogen levels decreased after treatment in non-survivors. ALT, total bilirubin, platelet, and $\mathrm{SpO}_{2}$ values increased and CRP and LDH values decreased after treatment in survivors.

Factors affecting the mortality of COVID-19 patients were examined (Table 3). Older age (OR): 1.04, 95\% [Confidence interval (Cl): 1.016-1.069], smoking (OR: $5.76,95 \% \mathrm{Cl}: 1.84-$ 18.03), presence of at least one or more comorbid diseases (OR: 4.43, 1.79-10.91), CAD (OR: 2.66, 95\% Cl: 1.06-6.72), arrhythmia (OR: $3.4,95 \% \mathrm{Cl}: 1.78-9.82)$ and CHF (OR:14.4,95\% $\mathrm{Cl}: 2.9-71.43)$ were statistically related to mortality $(p<0.05)$. Mortality was associated with treatment with lopinavir/ ritonavir (OR: 8.1, 95\% Cl 3.32-19.74) before favipiravir. Increased lymphocyte level (OR: 0.098, 95\% Cl: 0.03-0.29) and high $\mathrm{SpO}_{2}$ (OR: 0.99, 95\% Cl: 0.996-1.001) were related to reduced mortality. High CRP levels (OR: $1.01,95 \% \mathrm{Cl}$ : 1.008-1.019), radiological stage of disease (OR: $3.12,95 \% \mathrm{Cl}$ : 1.31-7.43) and transfer to ICUs from clinic departments (OR: $34.7,95 \% \mathrm{Cl}: 9.43-127.94)$ or directly admission to ICUs (OR: 390, 95\% Cl: 37.69-4035.3) were associated with increased mortality. 


\section{Discussion}

Dyspnea was revealed as a risk factor for mortality in patients with COVID-19 by Leung (8); however, there was no association between none of the symptoms including dyspnea and mortality in the present study. According to the results of this study, active smoking, older age, and presence of one or more comorbidities, (particularly CAD, arrhythmia and (HF) were associated with increased

\section{Table 1. The baseline characteristics of the patients treated with favipiravir}

\begin{tabular}{|c|c|c|c|c|}
\hline & $\begin{array}{l}\text { Total } \\
\mathrm{n}=148(\%)\end{array}$ & $\begin{array}{l}\text { Non-survivors } \\
\mathrm{n}=38(\%)\end{array}$ & $\begin{array}{l}\text { Survivors } \\
\mathrm{n}=110(\%)\end{array}$ & $p^{a}$ \\
\hline Age $($ Mean \pm SD) & $59.86 \pm 16.2$ & $67.3 \pm 13.3$ & $57.3 \pm 16.4$ & $<0.0001$ \\
\hline \multicolumn{5}{|l|}{ Gender } \\
\hline Female & $53(35.8)$ & $14(36.8)$ & 39 (35.5) & \multirow{2}{*}{0.87} \\
\hline Male & 95 (64.2) & $24(63.2)$ & 71 (64.5) & \\
\hline Smoking & $18(18)$ & $8(44.4)$ & $10(9.1)$ & 0.01 \\
\hline \multicolumn{5}{|l|}{ Symptoms } \\
\hline Fever & $128(86.5)$ & $33(86.8)$ & 95 (86.4) & 0.94 \\
\hline Cough & 97 (65.5) & $20(52.6)$ & 77 (70) & 0.052 \\
\hline GIS & $53(35.8)$ & 17 (44.7) & 36 (32.7) & 0.18 \\
\hline Diarrhea & $33(22.3)$ & $6(15.8)$ & 27 (24.5) & 0.26 \\
\hline Myalgia & 29 (19.6) & $5(13.2)$ & $24(21.8)$ & 0.25 \\
\hline Headache & $12(8.1)$ & $2(5.3)$ & $10(9.1)$ & 0.46 \\
\hline Anosmia/Disguise & $6(4.1)$ & $2(5.3)$ & $4(3.6)$ & 0.66 \\
\hline \multicolumn{5}{|l|}{ Comorbidities } \\
\hline CAD & $23(15.5)$ & $10(26.3)$ & $13(11.8)$ & 0.03 \\
\hline Arrhythmia & $16(10.8)$ & $8(21.1)$ & $8(7.3)$ & 0.02 \\
\hline Hypertension & $60(40.5)$ & $19(50)$ & $41(37.3)$ & 0.17 \\
\hline $\mathrm{CHF}$ & $10(6.8)$ & $8(21.1)$ & $2(1.8)$ & $<0.0001$ \\
\hline Diabetes & $37(25)$ & $14(36.8)$ & $23(20.9)$ & 0.051 \\
\hline COPD & $7(4.7)$ & $3(7.9)$ & $4(3.6)$ & 0.29 \\
\hline Asthma & $6(4.1)$ & $2(5.3)$ & $4(3.6)$ & 0.66 \\
\hline Malignancy history & $3(2)$ & $1(2.6)$ & $2(1.8)$ & 0.76 \\
\hline Comorbidity ( $\geqslant 1)$ & 86 (58.1) & 31 (81.6) & $55(50)$ & 0.001 \\
\hline Immunosuppression & $3(2)$ & - & $3(2.7)$ & 0.3 \\
\hline \multicolumn{5}{|l|}{ Radiological involvement } \\
\hline Mild & $2(1.4)$ & - & $2(1.8)$ & \multirow{4}{*}{0.002} \\
\hline Moderate & $56(37.8)$ & $8(21.1)$ & 48 (43.6) & \\
\hline Severe & $71(48)$ & $19(50)$ & $52(47.3)$ & \\
\hline Very Severe & $19(12.8)$ & $11(28.9)$ & $8(7.3)$ & \\
\hline \multicolumn{5}{|l|}{ Treatment Department } \\
\hline Clinic & $93(62.8)$ & $3(7.9)$ & 90 (81.8) & \multirow{3}{*}{$<0.0001$} \\
\hline Clinic + ICU & 41 (27.7) & $22(57.9)$ & $19(17.3)$ & \\
\hline ICU & $14(9.5)$ & $13(34.2)$ & $1(0.9)$ & \\
\hline Lopinavir/ritonavir before favipiravir & $29(19.6)$ & $18(47.4)$ & $11(10)$ & 0.0001 \\
\hline $\begin{array}{l}\text { Duration of hospitalization before starting } \\
\text { favipiravir (Mean } \pm \text { SD, day) }\end{array}$ & $3.5 \pm 2.6$ & $4.7 \pm 3.4$ & $3.1 \pm 2.2$ & 0.006 \\
\hline
\end{tabular}


Table 2. Comparison of laboratory parameters before and after favipiravir treatment

\begin{tabular}{|c|c|c|c|c|c|c|}
\hline \multirow[b]{2}{*}{ Parameter (Mean \pm SD) } & \multicolumn{2}{|c|}{ Non-survivors $(n=38)$} & \multirow[b]{2}{*}{$p^{a}$} & \multicolumn{2}{|c|}{ Survivors $(n=110)$} & \multirow[b]{2}{*}{$p^{a}$} \\
\hline & Pre-treatment & Post-treatment & & Pre-treatment & Post-treatment & \\
\hline $\mathrm{WBC}\left(\mathrm{K} / \mathrm{mm}^{3}\right)$ & $10.1 \pm 14.3$ & $14.83 \pm 9.9$ & 0.19 & $11.6 \pm 48.9$ & $10.7 \pm 39.9$ & 0.88 \\
\hline Lymphocyte $\left(\mathrm{K} / \mathrm{mm}^{3}\right)$ & $0.9 \pm 0.5$ & $1.057 \pm 0.9$ & 0.99 & $1.7 \pm 3.4$ & $2.6 \pm 9.7$ & 0.2 \\
\hline Neutrophil $\left(\mathrm{K} / \mathrm{mm}^{3}\right)$ & $7.6 \pm 4.4$ & $12.89 \pm 9.2$ & $<0.0001$ & $5.5 \pm 5.9$ & $4.5 \pm 2.7$ & 0.09 \\
\hline Platelet $\left(\mathrm{K} / \mathrm{mm}^{3}\right)$ & $229.7 \pm 121.7$ & $265.6 \pm 280.6$ & 0.42 & $209.2 \pm 80.9$ & $333.7 \pm 143.1$ & $<0.0001$ \\
\hline CRP (mg/L) & $137.5 \pm 73.3$ & $117.9 \pm 87.3$ & 0.27 & $69.5 \pm 63.9$ & $28.6 \pm 46.3$ & $<0.0001$ \\
\hline Ferritin (mg/L) & $1274.1 \pm 1766$ & $5326.46 \pm 103$ & 0.02 & $1533.4 \pm 4936$ & $2206.9 \pm 1147$ & 0.45 \\
\hline D-dimer $(\mu \mathrm{g} / \mathrm{L})$ & $3408.2 \pm 5028$ & $6223.9 \pm 8006$ & 0.06 & $1170.4 \pm 2258$ & $1017.7 \pm 1377$ & 0.55 \\
\hline LDH (U/L) & $790.2 \pm 350$ & $1048.4 \pm 829$ & 0.06 & $633.8 \pm 825$ & $439.4 \pm 161$ & 0.01 \\
\hline ALT (IU/L) & $30.6 \pm 19$ & $63.38 \pm 68$ & 0.006 & $43.0 \pm 73$ & $72.4 \pm 76$ & $<0.0001$ \\
\hline AST (IU/L) & $38.3 \pm 23$ & $99.21 \pm 124$ & 0.004 & $66.0 \pm 325$ & $54.0 \pm 191$ & 0.36 \\
\hline Total bilirubin (mg/dL) & $0.7 \pm 0.5$ & $3.004 \pm 8.8$ & 0.11 & $1.2 \pm 5$ & $5.1 \pm 20.5$ & 0.049 \\
\hline Direct bilirubin (mg/dL) & $0.3 \pm 0.2$ & $0.933 \pm 1.43$ & 0.01 & $0.3 \pm 0.2$ & $0.5 \pm 1.1$ & 0.2 \\
\hline $\mathrm{SpO}_{2}(\%)$ & $82.95 \pm 9.35$ & $76.39 \pm 1136$ & 0.003 & $90.28 \pm 3.72$ & $95.05 \pm 2.75$ & $<0.0001$ \\
\hline Fibrinogen $(\mu \mathrm{mol} / \mathrm{L})$ & $647.8 \pm 160.4$ & $576.37 \pm 222.3$ & 0.03 & $612.83 \pm 17.7$ & $605.72 \pm 193$ & 0.75 \\
\hline
\end{tabular}

Table 3. The risk factors associated with mortality

\begin{tabular}{|c|c|c|c|c|}
\hline Variable & OR & $\begin{array}{l}\text { Lower } \\
\text { (\%95 Cl) }\end{array}$ & $\begin{array}{l}\text { Upper } \\
\text { (\%95 Cl) }\end{array}$ & $p^{a}$ \\
\hline Age & 1.04 & 1.016 & 1.069 & $<0.05$ \\
\hline Smoking & 5.76 & 1.84 & 18.03 & $<0.05$ \\
\hline \multicolumn{5}{|l|}{ Comorbidities } \\
\hline CAD & 2.66 & 1.06 & 6.72 & $<0.05$ \\
\hline Arrhythmia & 3.4 & 1.78 & 9.82 & $<0.05$ \\
\hline $\mathrm{CHF}$ & 14.4 & 2.9 & 71.43 & $<0.05$ \\
\hline Comorbidity $(\geqslant 1)$ & 4.43 & 1.79 & 10.91 & $<0.05$ \\
\hline \multicolumn{5}{|l|}{ Laboratory parameters } \\
\hline Lymphocyte & 0.098 & 0.03 & 0.29 & $<0.05$ \\
\hline Radiological involvement & 3.12 & 1.31 & 7.43 & $<0.05$ \\
\hline $\mathrm{SpO}_{2}$ & 0.75 & 0.67 & 0.836 & $<0.05$ \\
\hline \multicolumn{5}{|l|}{ Treatment Department } \\
\hline Clinic + ICU & 34.7 & 9.43 & 127.94 & $<0.05$ \\
\hline ICU & 390 & 37.69 & 4035.3 & $<0.05$ \\
\hline $\begin{array}{l}\text { Lopinavir/ritonavir } \\
\text { treatment before } \\
\text { favipiravir }\end{array}$ & 8.1 & 3.32 & 19.74 & $<0.05$ \\
\hline
\end{tabular}

ap is significant at the level of $<0.05$. CAD: Coronary artery disease, CHF: Congestive heart failure, $\mathrm{SpO}_{2}$ : Oxygen saturation in room air, ICU: Intensive care unit OR: Odds Ratio

mortality in hospitalized severe and critically ill patients with COVID-19 treated with favipiravir. In a systematic review, the prevalence of current smoking was low among patients with COVID-19 in China, when compared to the population smoking prevalence (9). Zhou et al. (10) evaluated clinical course and risk factors for mortality in 191 adult patients hospitalized with the diagnosis of COVID-19 and there was no statistically significant difference in recovered and died patients in terms of active smoking (4\% and $9 \%$, respectively, $\mathrm{p}=0.21$ ). In a multi-center retrospective cohort study by Liu et al. (11), multivariate logistic regression analysis revealed that smoking was a risk factor for disease progression (OR: 14.285; 95\% Cl: 1.577-25.000; $p=0.018$ ). According to the present study results, the smoking rate was higher in nonsurvivors and smokers had 5.76 times more likely to die.

In the study evaluating the data of 72,314 patients diagnosed with COVID-19 in China, the case fatality rate increased with older age and comorbidity (12). Wang R. et al. (13) have concluded that older age, the presence of underlying disease, and smoking may be risk factors that cause the disease to worsen. These results are compatible with our results in this study. Although COPD was not identified as a risk factor for mortality in the present study, COPD and smoking history were associated with disease progression and poor clinical outcomes in a systematic review investigating the effect of COPD and smoking on COVID-19 severity (14).

Hypertension, diabetes, asthma, immunosuppression and malignancy history were not related to mortality according to this study. Patients with severe COVID-19 disease reported to have higher rates of cardiac comorbidities such as hypertension (58\%), coronary heart disease $(25 \%)$ and arrhythmia (44\%) (15). Patients with older age, male sex, 
chronic hypertension, and cardiovascular disease were found to be more common among non-survivors in another study (16). CAD, arrhythmia and CHF were more common in nonsurvivors and were significantly associated with mortality in the present study group. Although hypertension was more common in non-survivors, the difference was not statistically significant.

According to a meta-analysis, patients with severe and fatal disease had significantly increased white blood cell (WBC) count, and decreased lymphocyte and platelet counts compared to non-severe disease and survivors. Biochemical markers such as LDH, ALT,AST and total bilirubin, inflammation markers such as CRP, and ferritin, and coagulation markers such as D-dimer were also significantly elevated in patients with poor clinical outcome (17). In another study conducted to establish a prediction of disease progression, lymphocyte count, D-dimer and LDH were significantly different between patients with stable and severe disease (18). Lower lymphocyte level, decreased $\mathrm{SpO}_{2}$, high CRP level and advanced radiological stage of disease were related to increased mortality according to the results of this study. Other laboratory parameters including D-dimer, platelet, WBC, LDH, ferritin and fibrinogen were not risk factors for mortality in contrast with literature.

Lopinavir/ritonavir treatment before favipiravir was associated with increased mortality in patients treated with favipiravir in the present study. The efficacy of lopinavir/ ritonavir was investigated in COVID-19 patients in a randomized controlled study and there was no statistically significant difference in terms of clinical improvement and mortality in 28 days between the treatment group and the standard care group (19).

Favipiravir treatment started earlier in surviving patients. This finding supports the early initiation of favipiravir treatment to reduce mortality. Favipiravir treatment increased AST, direct bilirubin, neutrophil, and ferritin levels, and decreased $\mathrm{SpO}_{2}$ and fibrinogen levels in non-survivors. In survivors, ALT, total bilirubin, platelet and $\mathrm{SpO}_{2}$ increased, and CRP and LDH levels decreased with favipiravir treatment. Favipiravir increased the oxygenation of patients and decreased CRP and LDH levels in the present study. Mortality rate was higher in patients with increased ferritin levels.

The most important limitation of this study was that it was a retrospective observational study. It was not a clinical trial which was designed to evaluate favipiravir efficacy. This study may give direction for controlled studies in the future.

\section{Conclusion}

Older age, smoking, presence of one or more comorbidity, especially CAD, arrhythmia, and CHF, and treatment with lopinavir/ritonavir before favipiravir were associated with increased mortality in patients with severe and critical COVID-19 pneumonia treated with favipiravir. Favipiravir treatment increased $\mathrm{SpO}_{2}$ levels and platelet count, and decreased CRP and LDH levels in survivors. Increased ferritin may be a predictor of worsening of COVID-19. Early initiation of favipiravir treatment may be beneficial. Higher CRP levels at the beginning of treatment also increased the risk of mortality.

\section{Ethics}

Ethics Committee Approval: This study was approved by the Ethics Committee of the Umraniye Training and Research Hospital (125/April 28, 2020).

Informed Consent: Informed consent was waived because of the retrospective nature of the study.

Peer-review: Externally and internally peer-reviewed.

\section{Author Contributions}

Concept: T.Ç., Design: B.Ş., Data Collection or Processing: B.Ş., Analysis or Interpretation: T.Ç., Literature Search: B.Ş., Writing: T.Ç.

Conflict of Interest: The authors declare that they have no conflict of interest.

Financial Disclosure: The authors declared that this study received no financial support.

\section{References}

1. Dong L, Hu S, Gao J. Discovering drugs to treat coronavirus disease 2019 (COVID-19). Drug Discov Ther. 2020;14:58-60. [Crossref]

2. Du YX, Chen XP. Favipiravir: pharmacokinetics and concerns about clinical trials for 2019-nCoV infection. Clin Pharmacol Ther. 2020;108:242-247. [Crossref]

3. Oestereich L, Lüdtke A, Wurr S, Rieger T, Muñoz-Fontela C, Günther S. Successful treatment of advanced Ebola virus infection with T-705 (favipiravir) in a small animal model. Antiviral Res. 2014; 105:17-21. [Crossref]

4. Elfiky AA. SARS-CoV-2 RNA dependent RNA polymerase (RdRp) targeting: an in silico perspective.J Biomol Struct Dyn. 2020;1-9. [Crossref]

5. Yanai H. Favipiravir: A Possible Pharmaceutical Treatment for COVID-19.J Endocrinol Metab. 2020;10:33-34. [Crossref]

6. COVID-19 (SARS-CoV-2 Infection) Guide of Ministry of Health of Republic of Turkey, April 2, 2020. https://covid19bilgi.saglik.gov.tr/tr/[Crossref]

7. Bernheim A, Mei X, Huang M, Yang Y, Fayad ZA, Zhang N, et al. Chest CT findings in Coronavirus Disease-19 (COVID-19): relationship to duration of infection. Radiology. 2020;295:200463. [Crossref]

8. Leung C. Risk factors for predicting mortality in elderly patients with COVID-19: a review of clinical data in China. Mech Ageing Dev. 2020;188:111255. [Crossref]

9. Farsalinos K, Barbouni A, Niaura R. Systematic review of the prevalence of current smoking among hospitalized COVID-19 patients in China: could nicotine be a therapeutic option? Intern Emerg Med. 2020;15:845-852. [Crossref]

10. Zhou F, Yu T, Du R, Fan G, Liu Y, Liu Z, et al. Clinical course and risk factors for mortality of adult inpatients with COVID-19 in Wuhan, China: a retrospective cohort study. Lancet. 2020;395(10229):1054-1062. [Crossref] 
11. Liu W, Tao ZW, Wang L, Yuan ML, Liu K, Zhou L, et al. Analysis of factors associated with disease outcomes in hospitalized patients with 2019 novel coronavirus disease. Chin Med J (Engl). 2020;133:1032-1038. [Crossref]

12. Wu Z, McGoogan JM. Characteristics of and important lessons from the Coronavirus Disease 2019 (COVID-19) outbreak in China: summary of a report of 72314 cases from the Chinese center for disease control and prevention. JAMA. 2020;323:1239-1242. [Crossref]

13. Wang R, Pan M, Zhang X, Han M, Fan X, Zhao F, et al. Epidemiological and clinical features of 125 hospitalized patients with COVID-19 in Fuyang, Anhui, China. Int J Infect Dis. 2020;95:421-428. [Crossref]

14. Zhao $\mathrm{Q}$, Meng M, Kumar R, Wu Y, Huang J, Lian N, et al. The impact of COPD and smoking history on the severity of COVID-19: A systemic review and meta-analysis.J Med Virol. 2020;92:1915-1921. [Crossref]

15. lelapi N, Licastro N, Provenzano M, Andreucci M, Franciscis S, Serra R. Cardiovascular disease as a biomarker for an increased risk of COVID-19 infection and related poor prognosis. Biomark Med. 2020;14:713-716. [Crossref]

16. Chen T, Wu D, Chen H, Yan W, Yang D, Chen G, et al. Clinical characteristics of 113 deceased patients with coronavirus disease 2019: retrospective study. BMJ. 2020;368:m1091. [Crossref]

17. Henry BM, de Oliveira MHS, Benoit S, Plebani M, Lippi G. Hematologic, biochemical and immune biomarker abnormalities associated with severe illness and mortality in coronavirus disease 2019 (COVID-19): a metaanalysis. Clin Chem Lab Med. 2020;58:1021-1028. [Crossref]

18. Velavan TP, Meyer CG. Mild versus severe COVID-19: laboratory markers. Int J Infect Dis. 2020; 95:304-307. [Crossref]

19. Cao B, Wang Y, Wen D, Liu W, Wang J, Fan G, et al. A trial of lopinavirritonavir in adults hospitalized with Severe COVID-19. N Engl J Med. 2020;382:1787-1799. [Crossref] 